\title{
Interaksi Antara Negara Dan Desa Adat Dalam Konstruksi Negara Kesatuan Republik Indonesia
}

\author{
Andress Deny Bakarbessy \\ Fakultas Hukum Universitas Pattimura, Ambon, Indonesia \\ E-mail:denyboy64@gmail.com
}

\begin{abstract}
Indonesia is a unitary state that determines all regions of the country without exception constituting a unity of administrative and legal territory. However, in the territory of Indonesia there are also regions and unity of customary law communities, in this case the traditional village which has special characteristics that are special because it has existed before the formation of the State and has the right of origin in the administration of its government, and is recognized and respected by the State, so that the interaction between the State and customary villages allows conflicts between State law and customary law and traditions in the administration of government. For this reason, an ideal interaction between the State and the traditional village is needed which can create harmony and balance between the Country and the traditional village.
\end{abstract}

Keywords: Interaction, Unitary Republic of Indonesia, Traditional Village

\section{A. PENDAHULUAN}

Keberadaan Negara Kesatuan Republik Indonesia (NKRI) tidak dapat dipisahkan dari peristiwa Proklamasi Kemerdekaan 17 Agustus 1945 karena melalui peristiwa proklamasi tersebut bangsa Indonesia berhasil mendirikan negara yaitu Negara Kesatuan Republik Indonesia (NKRI).

Menurut C.S.T. Kansi ${ }^{1}$, Proklamasi Kemerdekaan Bangsa Indonesia secara garis besar dapat diartikan sebagai :

1) Lahirnya Negara Kesatuan Republik Indonesia (NKRI),

1 C.S.T. Kansil, 1984, Hukum Tata Negara Republik Indonesia, Bina Aksara, Jakarta, h, 267.
2) Puncak perjuangan pergerakan kemerdekaan, setelah berjuang berpuluh-puluh tahun sejak $20 \mathrm{Mei}$ 1908, dan

3) Titik tolak daripada pelaksanaan Amanat Penderitaan Rakyat. Sejarah pemerintahan Indonesia bermula semenjak Bangsa Indonesia memproklamasikan kemerdekaannya pada tanggal 17 Agustus 1945.

Menurut Hendarmin Ranadireksa bahwa Negara Kesatuan merupakan sistem kenegaraan yang menetapkan seluruh wilayah Negara tanpa kecuali merupakan suatu kesatuan wilayah 
administrasi dan hukum ${ }^{2}$. Hal tersebut berarti bahwa keberadaan daerah besar maupun daerah kecil, dengan berbagai bentuk susunan pemerintahannya, berada dalam suatu ikatan kesatuan yang tidak berdiri sendiri-sendiri.

Sementara itu, negara kesatuan seperti yang ditulis oleh Kranenburg ${ }^{3}$ adalah; "... negara kesatuan ialah organisasi bagian-bagian negara dalam garis besarnya telah ditetapkan oleh pembentuk undang-undang pusat .... Wewenang pembentuk undang-undang pusat ditetapkan dalam suatu rumusan yang umum dan wewenang pembentuk undang-undang rendahan (lokal) tergantung pada badan pembentuk undang-undang itu..."

Keberadaan Negara Kesatuan Republik Indonesia tidak dapat dilepas-pisahkan dari keberadaan berbagai daerah yang telah ada terbentuk sebelum adanya NKRI beserta berbagai keragaman dan ciri khas masing-masing, salah satunya adalah Desa sebagaimana diatur dalam penjelasan Pasal 18 UUD Tahun 1945 angka II bahwa:

Dalam territoir Negara Indonesia terdapat $\quad \pm 250 \quad$ "Zelfbesturende landschappen" dan Volksgemeenschappen, seperti desa di Jawa dan Bali, negeri di Minangkabau, dusun dan marga di Palembang dan sebagainya. Daerah-daerah itu mempunyai susunan Asli dan oleh karenanya dapat dianggap sebagai daerah yang bersifat istimewa.

Desa merupakan suatu institusi otonom dengan tradisi, adat istiadat dan hukumnya sendiri serta relatif mandiri ${ }^{4}$. Menurut Y Zakaria, sejatinya desa adalah negara kecil, karena sebagai masyarakat hukum, desa memiliki semua perangkat

2 Hendarmin Ranadireksa, 2009, Arsitektur Konstitusi Demokratik, Fokusmedia, Bandung, h, 58

Hendarmin Ranadireksa, 2009, Arsitektur Konstitusi .........Ibid, h, 62

${ }^{4}$ H A W Widjaja, 2004, Otonomi Desa Merupakan Otonomi yang Asli, Bulat dan Utuh, Raja Grafindo Persada, Jakarta, h, 4 suatu negara, seperti wilayah, warga, aturan dan pemerintahan. Selain itu, pemerintahan desa (adat) memiliki alat perlengkapan desa seperti polisi dan pengadilan yang memiliki kewenangan untuk menggunakan kekerasan didalam teritori atau wilayah hukumnya ${ }^{5}$. Berdasarkan hal inilah maka desa harus dipahami sebagai kesatuan masyarakat hukum yang memiliki hak dan kekuasaan dalam mengatur dan mengurus kepentingan masyarakatnya untuk mencapai kesejahteraan. Hak untuk mengatur dan mengurus kepentingan masyarakat inilah yang disebut otonomi desa $^{6}$.

Kondisi tersebut menunjukan bahwa Negara kesatuan merupakan suatu kesatuan wilayah dan pemerintahan yang tunduk dibawah Negara, termasuk Desa Adat dengan wilayah dan sistem pemerintahan yang di dasarkan pada hak asas usul, sehingga dapat menjadi pemicu atau menimbulkan ketegangan antara Negara dan Desa (adat) dalam penyelenggaran pemerintahan, mengingat Desa adat masih tetap memegang teguh sistem adat dalam penyelenggaraan pemerintahan, dapat bertentangan dengan pengaturan berdasarkan hukum Negara. Hal ini, misalnya dapat dilihat dalam penentuan kepala pemerintahan Desa adat di Maluku hanya berasal dari klan tertentu saja dan prosesnya melalui pengangkatan tanpa proses pemilihan. Sementara itu, Pasal 34 (1) UU No 6 Tahun 2014 tentang Desa menetapkan bahwa Kepala Desa dipilih langsung oleh penduduk Desa. Selain itu, masih terdapat praktik hukum adat lainnya yang dapat bertentangan dengan ketentuan dalam hukum Negara.

5 Y Zakaria, 2005, Pemulihan Kehidupan Desa dan UU No 22 Tahun 1999, Dalam Desentralisasi, Globalisasi, dan Demokrasi Lokal, LP3S, Jakarta, h,. 332

${ }^{6}$ H A W Widjaja, 2004, Otonomi Desa Merupakan Otonomi yang Asli ...... Op.Cit, h, 165 
Kondisi inilah yang dapat menjadi sumber perselisihan antara Desa adat dengan Negara. Berdasarkan hal tersebut maka persoalan yang akan dikaji adalah bagaimana Interaksi antara Negara dan Desa Adat Dalam Konstruksi Negara Kesatuan Republik Indonesia.

\section{B. PEMBAHASAN}

\section{Ciri Negara Kesatuan Republik Indonesia}

Proses kelahiran Bangsa Indonesia tersebut merupakan hasil dari perjuangan rakyat yang selama ratusan tahun tertindas dibawah kekuasaan kaum kolonialis pada saat itu, kondisi ketertindasan inilah yang kemudian mendorong para pemuda pada saat itu untuk membulatkan tekad demi mengangkat harkat dan martabat hidup orang Indonesia, tekad inilah yang menjadi komitmen perjuangan rakyat Indonesia hingga pada 17 Agustus 1945.

Para pendiri bangsa (the founding fathers) sepakat memilih bentuk negara kesatuan karena bentuk negara kesatuan dipandang paling cocok bagi bangsa Indonesia yang memiliki berbagai keanekaragaman, untuk mewujudkan paham negara integralistik (persatuan) yaitu negara hendak mengatasi segala paham individu atau golongan dan negara mengutamakan kepentingan umum.

Terbentuknya NKRI dimulai ketika Jepang memberikan kesempatan untuk merumuskan dasar Negara, pembukaan UUD, batang tubuh UUD, dan penjelasan UUD 1945 dengan dibentuknya Badan Penyelidik Usaha-usaha Persiapan Kemerdekaan Indonesia (BPUPKI/ Dokoritsu Zyunbai Tyoosakai) pada tanggal 29 April 1945 dengan dua masa sidang yaitu, 29 Mei - 1 Juni 1945 dan 10 - 17 Juli $1945^{7}$. Dimana, pada hari

7 Astim Riyanto, 2006, Negara Kesatuan (Konsep, Asas, dan Aktualisasi), Yapemdo, sidang yang pertama BPUPKI pada tanggal 29 Mei 1945 Muhammad Yamin berpidato dengan judul Asas dan Dasar Negara Kebangsaan Republik Indonesia, menyatakan bahwa Indonesia adalah Negara Kesatuan atas Paham Unitarisme... ${ }^{8}$. Hal tersebut menunjukan bahwa M. Yamin mengusulkan agar Negara Indonesia Merdeka berbentuk Negara Kesatuan ${ }^{9}$.

Pandangan M. Yamin ${ }^{10}$ terkait dengan Paham Negara Indonesia adalah menolak berbagai pemikiran tentang Negara dapat diuraikan sebagai berikut, bahwa ;

a) Negara Indonesia menolak segala tata Negara atau bagian - bagiannya yang melanggar dasar permusyawaratan, perwakilan dan pikiran

b) Negara Indonesia menolak paham:

1) Federalism

2) Feodalisme

3) Monarkhi

4) Liberalism

5) Autokrasi dan birokrasi

6) Demokrasi barat

c) Negara Rakyat Indonesia menolak segala dasar penjajahan dan segala sisa-sisa yang berasal dari zaman penjajahan. Negara indoensia ialah suatu Negara kebangsaan yang merdeka dan berdaulat penuh.

d) Negara Rakyat Indonesia menolak faham pemerintahan istibdadi seperti pemerintahan Firaun dan Namrud. Menolak faham pemerintahan Khila'ah, kekuasaan kerakyatan atas golongan yang berilmu dan berkhikmat. Menolak faham filsafatiah, yaitu pemerintahan kekuasaan cerdik pandai atas rakyat jelata.

Bandung, h, 183

8 Astim Riyanto, 2006, Negara

Kesatuan ...Ibid

9 Astim Riyanto, 2006, Negara Kesatuan....Ibid, h, 186

10 Risalah Sidang BPUPKI - PPKI, 28 Mei 1945-22 Agustus 1945, 1998, Sekertariat Negara Republik Indonesia, Jakarta, h, 23-24 
e) Negara Rakyat Indonesia menolak segala dasar penjajahan kolonialisme sebagai dasar pembentukan Negara.

f) Negara Rakyat Indonesia menolak segala tindakan yang akan mengecewakan kedaulatan Negara dengan menjalankan kebonekaan.

Berdasarkan penolakan terhadap keenam faham tersebut, maka Negara Rakyat Indonesia akan mewujudkan faham-faham ${ }^{11}$ :

a) Negara Rakyat Indonesia ialah suatu Negara persatuan yang tidak terpecah-pecah, dibentuk diatas dan didalam badan bangsa Indonesia yang tidak terbagi-bagi.

Negara Rakyat Indonesia Negara Kesatuan atas faham unitarisme.

b) Negara Rakyat Indonesia mempunyai satu kedaulatan yang dijunjung oleh Kepala Negara, dan oleh daerah, dan rakyat Indonesia..., serta pada point yang kedelapan yang menyatakan bahwa, Negara Rakyat Indonesia menjalankan pembagian pekerjaan Negara atas jalan Desentralisasi atau dekosentrasi yang tidak mengenal federalisme atau perpecahan Negara.

Soepomo dengan semangat Integralistik berpandangan bahwa Negara merupakan suatu susunan masyarakat yang integral, segala golongan, segala bagian, segala anggotanya berhubungan erat satu sama lain. Dalam Negara yang integral, Negara tidak memihak kepada suatu golongan yang paling kuat, atau yang paling besar, tidak menganggap kepentingan satu orang sebagai pusat, akan tetapi Negara menjamin keselamatan hidup bangsa seluruhnya sebagai persatuan yang tidak dapat dipisah-pisahkan ${ }^{12}$.

11 Risalah Sidang BPUPKI - PPKI, 28 Mei 1945-22 Agustus 1945.....Ibid, h, 24

12 Risalah Sidang BPUPKI - PPKI, 28
Lebih lanjut Soepomo menjelaskan bahwa dasar dan susunan suatu Negara berhubungan erat dengan riwayat hukum (rechtsgeschichte) dan lembaga social (social sructur) dari Negara tersebut. Hal tersebut membuat tiap-tiap Negara mempunyai keistimewaan sendiri-sendiri yang terkait dengan riwayat dan corak keistimewaan masyarakatnya. Untuk itu, dalam membangun Negara Indonesia harus juga disesuaikan dengan social culture masyarakat Indonesia berdasarkan pada persatuan dan kekeluargaan yaitu Negara yang bersatu dengan seluruh rakyatnya, dan mengatasi seluruh golongan-golongan dalam lapangan apapun ${ }^{13}$.

Berdasarkan pemikiran integralistik tersebut, maka Soepomo berpandangan bahwa semua golongan rakyat, segala daerah yang mempunyai keistimewaan sendiri, akan mempunyai tempat dan kedudukan sendiri-sendiri sebagai bagian organic dari Negara seluruhnya. Soal pemerintahan apakah yang akan diurus oleh pemerintah pusat dan soal apakah yang akan diserahkan kepada pemerintah daerah, baik daerah besar maupun daerah kecil, semuanya tergantung pada "doelmatigheid" yang berhubungan dengan waktu, soal dan tempatnya ${ }^{14}$.

Pemikiran Soepomo tersebut menurut Astim Riyanto ${ }^{15}$, merupakan usulan Soepomo agar Negara Indonesia yanga akan didirikan memiliki ciri:

1. Berbentuk Negara Kesatuan (eenheidsstaat)

2. Pengakuan dan penghormatan Negara terhadap daerah-daerah yang memiliki keistimewaan

3. Pembagian Negara atas daerah besar dan kecil

Mei 1945-22 Agustus 1945....Ibid, h, 52-53

13 Risalah Sidang BPUPKI - PPKI, 28

Mei 1945-22 Agustus 1945.....Ibid, h, 53-55

14 Risalah Sidang BPUPKI - PPKI, 28

Mei 1945-22 Agustus 1945......Ibid, h, 61

15 Astim Riyanto, 2006, Negara Kesatuan....Op.Cit, h, 184 
4. Negara berdasarkan asas Integralistik

5. Pembagian kekuasaan pada pemerintah daerah

Berdasarkan berbagai dinamika perjuangan mengenai keberadaan Negara kesatuan, maka setelah lahirnya Negara Indonesia pada tanggal 17 Agustus 1945 maka ditetapkan UUD tahun 1945. Dimana, kesepakatan Indonesia sebagai suatu Negara Kesatuan dituangkan dalam Pasal 1 ayat (1) UUD Tahun 1945 yang menyatakan bahwa Negara Indonesia adalah Negara Kesatuan yang berbentuk Republik, yaitu NKRI yang menghormati kedudukan daerah-daerah yang sifatnya istimewa, dan segala peraturan negara yang mengenai daerah-daerah itu akan mengingati hak-hak asal usul daerah tersebut. Oleh sebab itu, keberadaannya wajib tetap diakui dan diberikan jaminan keberlangsungan hidup bagi daerah daerah yang sifatnya istimewa dalam NKRI.

\section{Desa Adat Dalam Negara Kesatuan Republik Indonesia.}

Menurut Talizudhu Ndara bahwa terbentuknya desa, kerajaan, maupun kesultanan, sekaligus terbentuknya sistem ketatanegaraan dalam bentuk kesatuan perkampungan dan lain-lain, jauh sebelum Indonesia merdeka. Dimana, diseluruh Indonesia telah ada satuan-satuan masyarakat hukum yang mempunyai batas wilayah tertentu dan berwenang menyelenggarakan rumah tangganya sendiri. Satuan-satuan tersebut merupakan satuan ketatanegaraan karena mempunyai wilayah, penduduk, dan pemerintahan sendiri, yang disebut dengan desa, selain adanya kerajaan kerajaan atau kesultanan - kesultanan ${ }^{16}$.

Hal tersebut menunjukan bahwa jauh sebelum kedatangan bangsa Eropa

\begin{tabular}{llr}
\hline $16 \quad$ Talizudhu Ndraha, & 1981, \\
Dimensi-dimensi Pemerintahan & Desa, & Bina \\
Aksara, Jakarta, h, 23 &
\end{tabular}

ke Indonesia, maupun sebelum lahirnya NKRI, struktur masyarakat di Indonesia telah terbentuk, baik yang terbentuk berdasarkan kesatuan geanologis, territorial, maupun territorial genealogis. Hal tersebut terlihat dari adanya kampong, desa, maupun kerajaan yang telah ada dan hidup di Indonesia.

Pengakuan terhadap hak asal-usul pada awal pembentukan UUD 1945 merupakan konsep dari Soepomo yang mengusulkan agar desa, kuria, marga, gampong, dan lain-lain diakui oleh negara sebagai kesatuan masyarakat hukum yang berhak mengatur rumah tangganya karena memiliki susunan asli dan mempunyai sejarah asal usul yang jelas ${ }^{17}$.

Gagasan pendiri bangsa bahwa desa sebagai suatu komunitas otonom berdasarkan keaslian adat istiadat yang selalu dikaitkan dengan asal-usul senantiasa dihormati. Penghormatan tersebut ditunjukan dengan adanya pengakuan dalam konstitusi maupun dalam berbagai peraturan perundangan-undangan yang pernah mengatur mengenai desa ${ }^{18}$.

Penjelasan Pasal 18 UUD Tahun 1945 pada angka II yang menyatakan bahwa:

"Dalam territoir Negara Indonesia terdapat lebih kurang 250 zelfbesturende landchappen dan volksgetneenschappen, seperti desa di Jawa dan Bali, negeri di Minangkabau, dusun dan marga di Palembang dan sebagainya.

Daerah-daerah itu mempunyai susunan asli, dan oleh karenanya dapat dianggap sebagai daerah yang bersifat istimewa. Negara Republik Indonesia menghormati kedudukan

${ }^{17}$ Hanif Nurcholis, 2011, Pertumbuhan dan Penyelenggaraan Pemerintahan Desa, Erlangga, Jakarta, h, 212

18 Zudan Arif Fakrulloh, 2004, Kebijakan Desentralisasi di Persimpangan, Cipruy, Jakarta, h, 75 
daerah-daerah istimewa tersebut dan segala peraturan negara yang mengenai daerah-daerah itu akan mengingati hak-hak asal-usul daerah tersebut".

Dalam perkembangannnya amandemen terhadap UUD NRI Tahun 1945 memperkuat keberadaan masyarakat hukum adat dalam Konstitusi berdasarkan Pasal 18B ayat (2) UUD NRI Tahun 1945 yang mengatur bahwa:

Negara mengakui dan menghormati kesatuan-kesatuan masyarakat hukum adat serta hak-hak tradisonalnya sepanjang masih hidup dan sesuai dengan perkembangan masyarakat dan prinsip Negara Kesatuan Republik Indonesia, yang diatur dalam undang-undang.

Pengaturan Pasal 18B ayat (2) UUD NRI Tahun 1945 tidak secara tegas mengatur mengenai desa tetapi mengatur mengenai kesatuan-kesatuan masyarakat hukum adat. Menurut Ter Haar 19 Desa adalah satu kesatuan masyarakat hukum adat. Masyarakat hukum adat dinyatakan sebagai kelompok-kelompok teratur yang bersifat ajeg dengan pemerintah sendiri yang memiliki benda-benda material maupun imaterial (geordnede groepen van bhjvend karakter met eigen bewind en eigen materieel vermogen). Dengan ciri-ciri kesatuan masyarakat hukum adat adalah:

a) Masyarakatnya merupakan kelompok-kelompok teratur dan bersifat ajeg; maksudnya, masyarakat desa merupakan kelompok yang mematuhi suatu nilai dan norma tertentu (teratur) yang terus-menerus dipertahankan dan dikembangkan (bersifat ajeg).

b) Masyarakat desa memiliki pemerintahan sendiri, yaitu pemerintahan yang dibentuk dan

19 Dalam Hanif Nurcholis, 2011, Pertumbuhan dan Penyelenggaraan......Op.Cit, h, 16 dipertahankan oleh masyarakat sendiri; dan

c) memiliki benda-benda baik yang berwujud maupun yang tak berwujud.

Keberadaan desa adat merupakan suatu kenyataan sejarah yang tidak dapat dihindari atau bahkan disangkal oleh pemerintah. Masyarakat adat merupakan bagian riil di dalam masyarakat Indonesia, sehingga Negara wajib memberikan pengakuan terhadap eksistensi desa adat.

Menurut $\mathrm{Abu}$ daud Busroh ${ }^{20}$, Pengakuan (Erkenning/Recognisi) ada (dua) macam, yaitu:

1) Pengakuan de facto (sementara), yaitu pengakuan yang sifatnya sementara terhadap munculnya atau terbentuknya suatu Negara baru karena kenyataannya Negara baru tersebut secara kenyataan ada tetapi apakah prosedurnya melalui hukum masih diperdebatkan sehingga perlu diteliti lebih lanjut.

Berdasarkan hal tersebut, maka secara de facto Desa diakui karena berdasarkan kenyataan bahwa sistem adatnya masih tetap ada dan tetap berlaku.

2) Pengakuan de jure (Pengakuan Yuridis), yaitu pengakuan yang seluas-luasnya dan bersifat tetap terhadap munculnya atau timbulnya atau terbentuknya suatu Negara, dikarenakan terbentuknya Negara baru adalah berdasarkan hukum.

Berdasarkan konsep tersebut maka pegakuan secara de Jure (yuridis) terhadap Desa apabila keberadaannya datur oleh Negara dalam ketentuan peraturan perundang-undangan yang berlaku.

Dalam kaitan dengan pengakuan terhadap desa, maka dalam pandangan Moh. Yamin mengenai Pemerintahan

20 Abu Daud Busroh, 2009, Ilmu Negara, cet keenam, Bumi Aksara, Jakarta, h, 46 
Daerah dalam pidatonya tanggal 11 Juli 1945 di hadapan BPUPKI, yang antara lain mengatakan ${ }^{21}$ :

"Pemerintahan dalam Republik ini pertama-tama akan tersusun dari badan-badan masyarakat seperti desa, yaitu susunan pemerintah yang paling bawah, pemerintah ini saya namakan pemerintahan bawahan."

"Antara pemerintahan atasan dan pemerintahan bawahan itu adalah pemerintahan yang baik saya sebut pemerintahan tengahan. Perkara desa barangkali tidak perlu saya bicarakan di sini, melainkan kita harapkan saja, supaya sifatnya diperbaharui atau disesuaikan dengan keperluan zaman baru."

"Tetapi yang perlu ditegaskan di sini, yaitu bahwa desa-desa, negeri-negeri, warga-warga dan lainnya tetaplah menjadi kaki Pemerintahan Republik Indonesia. Dan di tengah-tengah pemerintahan atasan dan bawahan, kita pusatkan Pemerintah Daerah".

Pandangan M. Yamin tersebut menunjukan adanya keinginan untuk mempertahankan, memperbaharui dan menyesuaikan sistem pemerintahan desa dengan perkembangan zaman dengan menempatkan desa sebagai bagian dari sistem pemerintahan nasional.

Hal tersebut menunjukan bahwa terbentuknya pemerintahan NKRI bersumber dari adanya desa sebagai suatu pemerintahan terbawah di dalam masyarakat, yang kemudian membentuk daerah, dan pada akhirnya membentuk pemerintahan atasan dalam bentuk Negara.

Indonesia sebagai suatu Negara kesatuan hanya mengakui kekuasaan tertinggi di Negara melalui pemerintah pusat yang memberikan pengakuan bagi

21 Moh. Yamin dalam Mexasai Indra, 2011, Dinamika Hukum Tata Negara Indonesia, Refika Aditama, Bandung, h, 194 desa dengan berbagai hak asal-usulnya dengan tujuan agar berbagai tradisi adat istiadat yang masih ada dan hidup di desa dapat dimanfaatkan untuk memperkokoh tiang-tiang bangunan NKRI, bukan sebaliknya berbagai keragaman desa berdasarkan hak asal-usulnya digunakan untuk memperlemah Negara. berdasarkan pemikiran tersebut, maka pengakuan Negara terhadap otonomi yang dimiliki oleh desa harus sesuai dengan prinsip-prinsip NKRI, yaitu tidak melampaui kedaulatan Negara.

Berdasarkan hal tersebut, maka sebagai bagian integral dari Negara, maka desa ditempatkan sebagai satuan pemerintahan yang paling terbawah dan terdepan. Desa merupakan organisasi pemerintahan sekaligus kemasyarakatan yang terbawah, karena merupakan satuan organisasi pemerintahan yang paling kecil di dalam Negara. Sedangkan terdepan karena secara langsung berhadapan dengan masyarakat dengan segala permasalahan dan kepentingannya. Hal tersebut membuat keberadaan desa menjadi sangat strategis untuk dapat menyerap berbagai aspirasi dan kepentingan masyarakat, dan sebagai sarana untuk dapat menyalurkan berbagai aspirasi dan kepentingan masyarakat kepada pemerintah sehingga berbagai kebijakan pemerintah dapat secara efektif diterapkan di masyarakat.

Penempatan desa dalam sistem pemerintahan Negara merupakan pengakuan terhadap keberadaan desa yang menunjukan bahwa sebelum tata pemerintahan Negara terbentuk, tata pemerintahan desa telah ada sebelumnya $^{22}$.

Menurut Bagir Manan 23 dipertahankannnya sistem pemerintahan desa yang telah ada sebelum

22 Didik Sukirno, 2013 Hukum, Konstitusi dan Konsep Otonomi, SETARA Press, Malang, h, 183

23 Bagir Manan, 2004 Menyongsong Fajar Otonomi Daerah, cetakan III, Pusat Studi Hukum Fakultas Hukum UII, Yogyakarta, h, 158-159 
terbentuknya negara dimaksudkan untuk menjamin kehadiran satuan pemerintahan yang dekat dengan rakyat, sehingga keberadaan desa adat tidak hanya ditempatkan sebagai cermin sejarah pemerintahan masa lalu, tetapi disesuaikan dengan perkembangan zaman dan masyarakat, sehingga harus menjadi bagian integral pemerintahan dalam menjalankan fungsi-fungsi pemerintahan tanpa harus meniadakan nilai-nilai serta fungsi-fungsi tradisional yang masih hidup dan terpelihara.

Dengan demikian, Desa adat juga memiliki fungsi pemerintahan, keuangan Desa, pembangunan Desa, serta mendapat fasilitasi dan pembinaan dari pemerintah Kabupaten/Kota. Dalam kondisi seperti ini maka Desa Adat mendapat pengakuan dan penghormatan dari Pemerintah dan Pemerintah Daerah.

Berdasarkan pemikiran tersebut, maka berbagai pengaturan yang terkait dengan desa dalam bentuk UU telah menempatkan desa sebagai bagian dari sistem pemerintahan nasional. Hal tersebut dapat dilihat dalam:

1) UU No 1 Tahun 1945 yang menempatkan desa sebagai daerah otonom terbawah serta sebagai kesatuan masyarakat yang berhak mengatur urusan rumah tangganya sendiri.

2) UU No 22 Tahun 1948 yang memberikan pengakuan dan perlindungan terhadap eksistensi desa sebagai kesatuan masyaraat yang memiliki hak asal-usul dan berhak mengurus pemerintahannya sendiri, dan menempatkan desa sebagai daerah otonom tingkat III.

3) UU No 1 Tahun 1957 yang membagi daerah otonom menjadi dua jenis, yaitu daerah otonom biasa dan daerah swapraja.

4) UU No 19 Tahun 1965 yang menyeragamkan desa dalam bentuk desapraja, yang akan ditempatkan sebagai daerah tingkat III.

5) UU No 5 Tahun 1979 yang menyeragamkan nama, bentuk maupun susunan desa yang ditempatkan di bawah kecamatan.

6) UU No 22 Tahun 1999 yang memberikan pengakuan terhadap keragaman desa tetapi menempatkan desa sebagai bagian dari pemerintahan daerah kabupaten/kota.

7) UU No 32 Tahun 2004 yang mengakui hak asal-usul desa dengan keragamannya tetapi juga menempatkan desa sebagai sub sistem pemerintah daerah kabupaten/kota.

UU No 6 Tahun 2014 yang membedakan desa dengan dengan desa adat. Desa adat diakui hak asal-usul desa dengan keragamannya, desa adat juga dijadikan bagian dari sistem pemerintahan nasional.

\section{Interaksi Negara dan Desa Adat Dalam Negara Kesatuan Republik Indonesia}

Pemikiran mengenai terbentuknya NKRI tidak dapat dipisahkan dari berbagai pemikiran mengenai terbentuknya suatu kesatan teritorial dibawahnya, seperti Desa dan Daerah. Hal tersebut disebabkan karena, terbentuknya suatu negara akan didahului oleh terbentuknya suatu desa. Oleh karena itu, terdapat suatu keterkaitan yang erat antara Negara, Daerah, dan Desa sebagaimana pandangan J. Stahl ${ }^{24}$ yang dikutip Soehino mengenai perkembangan negara bahwa negara terjadi karena perkembangan dari suatu keluarga yang bersifat patriakal yang menempati suatu daerah. Hal tersebut didasari karena sejarah dan persamaan nasib, kebutuhan dan sebagainya yang telah melawati beberapa phase, yang kemudian melahirkan bangsa, dan dari bangsa inilah kemudian membentuk

24 Soehino, Ilmu Negara, liberty, Yogyakarta, h, 129 
negara.

Pandangan tersebut juga sesuai dengan teori organis Aristoteles yang kemudian didukung oleh John Althus yang menyatakan bahwa negara adalah persekutuan daripada keluarga dan desa guna memperoleh hidup yang sebaik-baiknya ${ }^{25}$. Negara itu diawali dari manusia, manusia itu kemudian membentuk keluarga, masing-masing keluarga itu bersatu dan membentuk desa, desa-desa yang ditinggali keluarga kemudian membentuk negara atau polis, dengan tujuan untuk dapat mempertahankan diri dari serangan musuh $^{26}$.

Berdasarkan pengalaman sejarah di Indonesia perkembangan desa dimulai dari adanya seseorang yang mempunyai pengaruh besar sehingga dapat menggerakkan banyak orang untuk menjadi pengikutnya. kemudian mengajak "para pengikutnya" tersebut untuk membuka hutan atau lahan kosong untuk dijadikan permukiman baru. Kemudian berdiam atau tinggal di wilayah tersebut yang dalam perkembangannya disebut sebagai desa. Setelah desa terbentuk, maka sang tokoh tersebut membentuk tata pemerintahannya, dan menjadi kepala desa pertama yang dibantu oleh kerabatnya. Umumnya susunan lembaga pemerintahnya terdiri atas kepala desa yang dibantu dengan beberapa petugas yang diperlukan ${ }^{27}$.

Komunitas tersebut, kemudian menjelma sebagai organisasi komunitas lokal yang mempunyai batas-batas wilayah, dihuni oleh sejumlah penduduk, dan mempunyai adat-istiadat untuk mengelola dirinya sendiri. Desa

${ }^{25}$ Sri Soemantri Martosoewignjo, 1976, Sistem-Sistem Pemerintahan Negara-Negara ASEAN. Bandung, Tarsito, h, 3.

26 Ateng Syafrudin dan Suprin Na'a, 2010, Republik Desa - Pergulatan Hukum Tradisional dan Hukum Modern Dalam Desain Otonomi Desa, Alumni, Bandung, h, 10

27 Hanif Norcholis, 2011, Pertumbuhan dan Penyelenggaraan......Op.Cit, h, 9 pada umumnya mempunyai pemerintahan sendiri yang dikelola secara otonom tanpa ikatan hirarkis struktural dengan struktur yang lebih tinggi ${ }^{28}$.

Dengan demikian, desa secara sederhana merupakan negara kecil, karena memiliki wilayah, penduduk dan pemerintahan secara adat yaitu hak untuk menyelenggarakan pemerintahan berdasarkan hak asal-usul yang dimilikinya. Dengan demikian, di Indonesia terdapat lebih kurang 250 zelfbesturende landchappen dan volksgetneenschappen, seperti desa di Jawa dan Bali, negeri di Minangkabau, dusun dan marga di Palembang dan sebagainya dengan berbagai hak asal usul masing-masing.

Hal tersebut menunjukan bahwa bangsa Indonesia adalah bangsa yang beragam dengan latar belakang keragaman baik dari sisi geografis, ras, suku, bahasa maupun agama. Keragaman tersebut membentuk keragaman sistem bermasyarakat dan adat istiadat yang dipatuhi dan dijalankan oleh masyarakatnya, memiliki struktur dan norma-norma tersendiri yang tetap hidup dan dipatuhi oleh anggotanya disebut sebagai masyarakat hukum adat ${ }^{29}$.

Masyarakat Indonesia sebagai suatu masyarakat yang bersifat heterogen dan pluralis karena terdiri dari berbagai macam suku, dengan latar belakang budaya, agama dan tatanan budayanya ${ }^{30}$, berdasarkan hal tersebut maka setiap kelompok masyarakat mengembangkan hukum kebiasaannya sendiri karena

28 Hanif Norcholis, 2011, Pertumbuhan dan Penyelenggaraan.......Ibid, h, 11

29 Jenedri M Gaffar, 2012, Demokrasi Konstitusional - Praktik Ketatanegaraan Indonesia Setelah Perubahan UUD 1945, Konstitusi Press, Jakarta, h, 159

${ }^{30}$ Liria Tjahja, 2003, Pluralisme Hukum Dan Masalah Perkawinan Campuran Dalam Hukum dan Kemajemukan Budaya (Sumbangan Karangan Untuk Menyambut HUT ke-70 Prof. Dr. T.O. Ihromi), Yayasan Obor Indonesia, Jakarta, h, 115 
mempunyai bahasa dan adat istiadat yang khas sehingga jiwa atau semangat rakyat (volksgeist) dari suatu bangsa akan terlihat dalam hukumnya.

Implementasi yang terjadi adalah desa tidak saja memiliki wewenang unruk mengatur dan mengurus kepentingan masyarakatnya berdasarkan hak asal-usulnya semata, tetapi juga menyelenggarakan urusan pemerintahan yang didasarkan pada hukum Negara.

Berdasarkan hal tersebut, maka terdapat 2 (dua) hukum yang mengatur kehidupan di desa, yaitu hukum Negara dan hukum local (adat). Menurut Sally Engle Marry bahwa pluralisme hukum difokuskan pada berlakunya dua sistem hukum yang hidup secara berdampingan dan berkembang dalam kehidupan sosial kemasyarakatan. Hal tersebut berarti bahwa antara hukum Negara dan hukum lokal berlaku bersama-sama dalam kehidupan masyarakat maka itulah pluralisme hukum ${ }^{31}$, misalnya dalam pemilihan kepala pemerintahan desa adat yang masih mempertahankan tradisi merupakan hak dari klan tertentu dan prosesnya hanya melalui pengangkatan, sedangkan menurut hukum Negara yaitu UU Desa bahwa kepala pemerintahan di desa harus dipilih, ataupun dalam proses penyelesaian suatu tindakan kejahatan di desa, maka terdapat hukum Negara melalui sistem peradilan pidana sebagai penyelesaian formal berdasarkan hukum Negara dan hukum adat yang tidak tertulis sebagai sarana penyelesaiannya.

Dalam kaitan dengan hal tersebut, menurut Marc Galanter bahwa pencarian keadilan tidak hanya di dapatkan di ruang pengadilan melalui hukum Negara, akan tetapi juga terdapat di luar ruang pengadilan melalui hukum adat. ${ }^{32}$

31 H. Salim dan Erlies Septiana Nurbani, 2013, Penerapan Teori Hukum pada Penelitian Tesis dan Disertasi, Rajawali Press, Jakarta, h, 96-97

32 Marc. Galanter, 1993, Keadilan di Berbagai Ruangan: Lembaga Peradilan, Penataan Masyarakat serta Hukum Rakyat dalam T.O. Ihromi (Penyunting), Antropologi Hukum
Hal tersebut sejalan dengan pandangan Satjipto Rahardjo ${ }^{33}$ bahwa persoalan yang terjadi didalam masyarakat yang masih memegang teguh nilai-nilai adatnya, maka akan diselesaikannya tanpa pernah tahu mengenai keberadaan hukum nasional yang mengatur mengenai persoalan yang hadapi, akan tetapi lebih dikedepankan nilai-nilai yang telah hidup di dalam masyarakatnya untuk menyelesaikan permasalahan atau konflik tersebut.

Menurut Eka Dharmaputra bahwa persoalan yang dihadapi dalam kaitan dengan adanya interaksi antara hukum Negara dan hukum local adalah persoalan identitas dan modernitas. Hal tersebut terkait dengan bagaimana mempertahankan identitas tanpa menghambat kemajuan, dan bagaimana mencapai kemajuan tanpa mengorbankan identitas ${ }^{34}$. Desa yang dikonotasikan sebagai habitatnya adat istiadat (hukum adat) merupakan cerminan identitas desa adat akan bersinggungan dengan hukum Negara yang mewakili modernitas. Dengan demikian, desa merupakan tempat untuk bertemunya hukum adat yang didasarkan pada hak asal-usul, dan hukum Negara sebagai instrument untuk menjalankan kekuasaan negara.

Hasil interaksi diantara hukum negara dan hukum adat sering juga menciptakan ketidaksesuaian diantara keduanya sehingga konflik seringkali tidak terhindarkan. Hal tersebut sering menimbulkan kecendrungan bagi mayarakat untuk taat pada salah satu hukum saja dan cendrung menolak pemberlakuan hukum yang lain ${ }^{35}$.

sebuah Bunga Rampai, Yayasan Obor, Jakarta, h, 81

33 Satjipto Rahardjo 2008, Biarkan Hukum Mengalir, Penerbit Buku Kompas, Jakarta, h, 44

34 Eka Dahrmaputera, 1997, Pancasila-identitas dan Modernitas, BPK Gunung Mulia, Jakarta, h, 5

35 Ade Saptomo, 2010, Otonomi dan Kebangkitan Daerah : Sebuah Test Case Dalam Hukum dan Kearifan Lokal, Grasindo, Jakarta, h, 30 
Bernard Tanya menguraikan bahwa benturan antara budaya (hukum adat) dengan hukum yang modern (hukum Negara) memberikan beban bagi masyarakat yang masih memlihara dan hidup dengan adat istiadatnya, karena hanya untuk menyenangkan Negara maka hukum Negara akan ditaati, sedangkan hukum adat terpaksa harus dikesampingkan untuk sementara ${ }^{36}$.

Sementara itu, menurut Eka Dharmaputra bahwa dalam kehidupan bernegara dan bermasyarakat dalam suatu masyarakat yang pluralis, pemegang kekuasaan cendrung menghadapi persoalan yang terkait dengan membatasi kebebasan berbagai kelompok masyarakat, demi kepentingan masyarakat secara keseluruhan ${ }^{37}$.

Adanya pengorbanan masyarakat untuk membatasi kebebasannya, baik secara pribadi maupun berbagai kelompok yang berbeda untuk kepentingan masyarakat secara keseluruhan menunjukan bahwa telah terjadi kesepakatan di dalam masyarakat dan menunjukan bahwa terciptanya integrasi dalam masyarakat. Kesepakatan tersebut pada dasarnya adalah sebuah aturan hidup bersama yang diakui keberlakuannya di dalam masyarakat.

Hal tersebut menunjukan bahwa kehidupan bersama dapat diwujudkan apabila anggota-anggota masyarakat bersedia mematuhi dan mengikuti berbagai aturan yang telah disepakati bersama atau pola tingkah laku yang normatif. Hal ini menunjukan bahwa telah terjadi integrasi norma di dalam masyarakat, dimana masyarakat bersedia dibatasi kebebasannya atau meninggalkan kebiasaannya (individu atau kelompok) untuk melahirkan kesepakatan bersama di dalam masyarakat. Akan tetapi, hal tersebut tidak hanya sebatas aturan

36 Bernard L Tanya, 2006, Hukum Dalam Ruang Sosial, Genta Publishing, Yogyakarta, h, 166 $7-8$ semata, tetapi persoalan yang seharusnya di dalam masyarakat bukan sekedar aturan yang sifat normatif tetapi persoalan nilai atau semacam pandangan hidup bersama yang dianggap baik dan benar, dan tidak hanya sifatnya mengatur dan membatasi ${ }^{38}$.

Menurut Theodore Steeman yang dikutip oleh Eka Dharmaputera ${ }^{39}$ bahwa masyarakat tidak hanya membutuhkan integrasi norma, tetapi juga integrasi nilai, yaitu kosepsi tentang pemahaman mengenai hidup, bagaimana hidup harus dijalani serta komitmen dasar yang menjadi penuntun dalam kehidupan bersama.

Kenyataan yang terjadi terkait dengan interaksi di antara hukum negara dengan hukum adat di tingkat desa memiliki kecendrungan untuk melahirkan konflik mengingat kedua sistem hukum tersebut memiliki sifat dan karakter yang berbeda. Menurut Dean Pruit dan Jeffrey Rubin $^{40}$, konflik bukan hanya terkait dengan suatu perkelahian, peperangan, perjuangan atau berupa konfrontasi fisik antara beberapa pihak. Akan tetapi, konflik juga meliputi ketidaksepakatan yang tajam atau oposisi atas berbagai kepentingan, ide atau lain-lain.

Berdasarkan hal tersebut, maka adanya interaksi antara hukum negara yang sarat dengan bentuk-bentuk formal, prosedur-prosedur dan birokrasi penyelenggaraan publi ${ }^{41}$ serta merupakan cerminan kehendak penguasa dalam mengatur masyarakatnya 42 , dengan hukum adat yang bersumber dari tradisi yang didasarkan pada pengalaman turun temurun ${ }^{43}$, tidak dapat dilakukan dalam

38 Eka Dahrmaputera, 1997...Ibid, hl. 8

39 Eka Dahrmaputera, 1997...Ibid

40 Dean Pruit dan Jeffrey Rubin, Social Conflict, diterjemahkan oleh Helly P Soetjipto dan Sri Mulyani Soetjipto, 2011, Teori Konflik Sosial, Pustaka Pelajar, Yogyakarta, h, 9

41 Satjipto Rahardjo, 2010, Penegakan Hukum Progresif, Penerbit Buku Kompas, Jakarta, h, 223

${ }^{42}$ Liria Tjahja, 2003...Op.Cit, h. 116

43 E.K.M. Masinambow, 2003, Hukum dan Kemajemukan Budaya Dalam Hukum dan 
tataran norma melainkan pada tataran nilai.

Terkait dengan hal tersebut, maka salah satu contoh interaksi hukum negara dan hukum adat di desa adat adalah terkait dengan pemilihan kepala desa. Berdasarkan nilai-nilai dalam hukum adat di Maluku, calon pemimpin di desa hanya berasal dari kelompok kekeluargaan tertentu saja, hal tersebut dapat dikatakan tidak sesuai dengan prinsip-prinsip demokrasi. Menurut Jenedri M Gaffar bahwa demokrasi mengandung nilai-nilai yang menolak adanya diskriminasi, mengakui persamaan atau kesederajatan manusia serta kemanusian, dalam kehidupan berbangsa dan bernegara ${ }^{44}$.

Hal tersebut jika dikaitkan dengan sistem pemilihan pemimpin desa di Maluku yang di dasarkan pada hak-hak istimewa berdasarkan sistem kekerabatan tertentu, maka dapat dikatakan tidak sesuai atau bertentangan dengan prinisip demokrasi. Akan tetapi, mekanisme pemilihan pemimpin di desa adat Maluku tidak hanya berdasarkan sistem kekeluargaan semata, akan tetapi terdapat mekanisme musyawarah dari semua komponen perwakilan masyarakat desa dalam memilih pemimpinnya, baik itu musyarah untuk menentukan calon pemimpin yang dilakukan oleh keturunan yang memiliki hak untuk menjadi pemimpin, kemudian musyawarah dilakukan oleh perwakilan masyarakat untuk menyetujuinya atau menolaknya. Selain itu, terdapat juga mekanisme untuk memberikan mandat kepada kelompok kekeluargaan yang lain, jika tidak terdapat calon pemimpin yang berasal dari kelompok kekeluargaan yang mempunyai hak untuk menjadi pemimpin tersebut.

Menurut Suteki, setiap bangsa pada dasarnya memiliki sistem nilai yang mengikat warganya, dalam konteks Indonesia, maka Pancasila merupakan

Kemajemukan Budaya (Sumbangan Karangan Untuk Menyambut HUT ke-70 Prof. Dr. T.O. Ihromi), Yayasan Obor Indonesia, Jakarta, h, 10

44 Jenedri M Gaffar, 2012...Op.Cit, h, 11 sistem nilai yang harus digunakan sebagai pedoman untuk mengembangkan dan mencapai tujuan nasional sebagaimana yang telah disepakati oleh founding fathers di awal kemerdekaan ${ }^{45}$.

Bentuk demokrasi yang dipraktikan oleh masyarakat di Maluku adalah musyawarah untuk mencapai kata sepakat atau mufakat, yang telah ada dan dipelihara secara turun temurun oleh masyarakat. Menurut Jimly Asshiddiqie ${ }^{46}$, salah satu wujud hukum tata negara adat yang menjadi ciri ketatanegaraan Indonesia adalah prinsip musyawarah. Musyawarah diperlukan agar penyelenggara negara dapat menjalankan tugasnya mewujudkan keadilan sosial sesuai dengan cita-cita rakyat. Musyawarah merupakan forum pengambilan keputusan sekaligus pembatasan kekuasaan.

Menurut sifat tatanegara Indonesia yang asli, yang sampai sekarangpun masih dapat terlihat dalam suasana desa baik di Jawa, maupun di Sumatera dan kepulauan-kepulauan Indonesia lain, maka para penjabat negara ialah pemimpin yang bersatu-jiwa dengan rakyat dan para penjabat negara senantiasa berwajib memegang teguh persatuan dan kesimbangan dalam masyarakatnya. Sebagaimana yang disampaikan oleh M.Yamin ${ }^{47}$ bahwa prinsip musyawarah merupakan sifat peradaban bangsa Indonesia yang asli, bahkan sebelum masuknya Agama. Prinsip musyawarahlah yang menyusun masyarakat dan ketatanegaraan berdasarkan keputusan bersama .

Hal tersebut terimplementasi oleh Negara Kesatuan Republik Indonesia yang menganut paham kedaulatan rakyat, yang tercermin dari pembukaan UUD

45 Suteki, 2013 Desain Hukum Dalam Ruang Sosial, Tahafa Media, Yogyakarta, h, 188

46 Jimly Asshiddiqie, 2008, Konstitusi dan Hukum Tata Negara Adat, Makalah, disampaikan pada Seminar Nasional tentang Konstitusi Kesultanan-Kesultanan Islam di Jawa Barat dan Banten. UIN Gunung Djati, Bandung, h, 5

47 Jimly Asshiddiqie, 2008...Ibid 
NRI Tahun 1945 alinea ke-4 yang menyatakan bahwa ...maka disusunlah kemerdekaan Indonesia itu dalam suatu Undang-undang Dasar Negara Republik Indonesia yang terbentuk dalam susunan Negara Indonesia yang berkedaulatan Rakyat....Dengan demikian, NKRI adalah negara yang berkedaulatan rakyat yang dalam pelaksanaannya menganut prinsip kerakyatan yang dipimpin oleh hikmat kebijaksanaan dalam permusyawaratan perwakilan sebagimana diatur dalam sila ke-4 dari Pancasila ${ }^{48}$, sebagaimana yang juga dipraktikan oleh masyarakat Maluku dalam proses pemilihan pemimpin di Desa adat.

Berdasarkan hal tersebut, maka integrasi nilai-nilai yang hidup dan masih dipertahankan oleh Desa adat dan nilai-nilai yang terkandung dalam hukum Negara diperlukan untuk menciptakan interaksi yang harmonis dan seimbang antara Negara dan Desa adat.

Dengan demikian, adanya integrasi nilai diantara hukum negara dan hukum adat diharapkan dapat mengurangi terjadinya konflik dalam interaksi antara Negara dan Desa adat dalam penyelenggaraan pemerintahan dan pembangunan di Desa adat.

\section{PE N U T U P}

Berdasarkan berbagai uraian pada hasil penelitian dan pembahasan maka kesimpulan yang dapat disampaikan adalah: Negara Kesatuan Republik Indonesia adalah Negara yang mengakui dan menghormati kesatuan masyarakat hukum adat beserta hak-hak asal usul. Wujud pengakuan dan penghormatan tersebut adalah menempatkan Desa adat sebagai bagian dari sistem pemerintahan nasional. Hal ini membuat terjadinya

48 Hendrik Salmon, 2010, Keseimbangan Kewenangan Antara DPR dan DPD Sebagai Sarana Perwujudan Demokrasi Dalam Sistem Ketatanegaraan Indonesia, Ringkasan Disertasi, Program Pasca Sarjana Unhas-Fakultas Hukum, Makassar, h, 3 interaksi antara hukum adat dan hukum Negara yang berpotensi melahirkan konflik antara Negara dan desa adat. Untuk itu, diperlukan integrasi nilai dalam membangun interaksi antara Negara dan Desa Adat dalam penyelenggaraan pemerintahan dan pembangunan di Desa adat.

\section{DAFTAR PUSTAKA}

Abu Daud Busroh, 2009, Ilmu Negara, cet keenam, Bumi Aksara, Jakarta

Ade Saptomo, 2010, Otonomi dan Kebangkitan Daerah : Sebuah Test Case Dalam Hukum dan Kearifan Lokal, Grasindo, Jakarta

Astim Riyanto, 2006, Negara Kesatuan (Konsep, Asas, dan Aktualisasi), Yapemdo, Bandung

Ateng Syafrudin dan Suprin Na'a, 2010, Republik Desa - Pergulatan Hukum Tradisional dan Hukum Modern Dalam Desain Otonomi Desa, Alumni, Bandung

Bagir Manan, 2004 Menyongsong Fajar Otonomi Daerah, cetakan III, Pusat Studi Hukum Fakultas Hukum UII, Yogyakarta

Bernard L Tanya, 2006, Hukum Dalam Ruang Sosial, Genta Publishing, Yogyakarta

C.S.T., Kansil, 1984, Hukum Tata Negara Republik Indonesia, Bina Aksara, Jakarta

Dean Pruit dan Jeffrey Rubin, Social Conflict, diterjemahkan oleh Helly $P$ Soetjipto dan Sri Mulyani Soetjipto, 2011, Teori Konflik Sosial, Pustaka Pelajar, Yogyakarta

Didik Sukirno, 2013 Hukum, Konstitusi dan Konsep Otonomi, SETARA Press, Malang

Eka Dahrmaputera, 1997, Pancasila Identitas dan Modernitas, BPK Gunung Mulia, Jakarta

E.K.M. Masinambow, 2003, Hukum dan Kemajemukan Budaya Dalam Hukum dan Kemajemukan Budaya (Sumbangan Karangan Untuk Menyambut HUT ke-70 Prof. Dr. 
T.O. Ihromi), Yayasan Obor Indonesia, Jakarta

H A W Widjaja, 2004, Otonomi Desa Merupakan Otonomi yang Asli, Bulat dan Utuh, Raja Grafindo Persada, Jakarta

Hendarmin Ranadireksa, 2009, Arsitektur Konstitusi Demokratik, Fokusmedia, Bandung

Hanif Nurcholis, 2011, Pertumbuhan dan Penyelenggaraan Pemerintahan Desa, Erlangga, Jakarta

H. Salim dan Erlies Septiana Nurbani, 2013, Penerapan Teori Hukum pada Penelitian Tesis dan Disertasi, Rajawali Press, Jakarta

Hendrik Salmon, 2010, Keseimbangan Kewenangan Antara DPR dan DPD Sebagai Sarana Perwujudan Demokrasi Dalam Sistem Ketatanegaraan Indonesia, Ringkasan Disertasi, Program Pasca Sarjana Unhas-Fakultas Hukum, Makassar

Jenedri M Gaffar, 2012, Demokrasi Konstitusional - $\quad$ Praktik Ketatanegaraan Indonesia Setelah Perubahan UUD 1945, Konstitusi Press, Jakarta

Jimly Asshiddiqie, 2008, Konstitusi dan Hukum Tata Negara Adat, Makalah, disampaikan pada Seminar Nasional tentang Konstitusi Kesultanan-Kesultanan Islam di Jawa Barat dan Banten. UIN Gunung Djati, Bandung

Liria Tjahja, 2003, Pluralisme Hukum Dan Masalah Perkawinan Campuran Dalam Hukum dan Kemajemukan Budaya (Sumbangan Karangan Untuk Menyambut HUT ke-70 Prof. Dr. T.O. Ihromi), Yayasan Obor Indonesia, Jakarta

Marc. Galanter, 1993, Keadilan di
Berbagai Ruangan: Lembaga Peradilan, Penataan Masyarakat serta Hukum Rakyat dalam T.O. Ihromi (Penyunting), Antropologi Hukum sebuah Bunga Rampai, Yayasan Obor, Jakarta

Mexasai Indra, 2011, Dinamika Hukum Tata Negara Indonesia, Refika Aditama, Bandung

Y Zakaria, 2005, Pemulihan Kehidupan Desa dan UU No 22 Tahun 1999, Dalam Desentralisasi, Globalisasi, dan Demokrasi Lokal, LP3S, Jakarta, hl. 332

Risalah Sidang BPUPKI - PPKI, 28 Mei 1945-22 Agustus 1945, 1998, Sekertariat Negara Republik Indonesia, Jakarta

Satjipto Rahardjo 2008, Biarkan Hukum Mengalir, Penerbit Buku Kompas, Jakarta

Satjipto Rahardjo, 2010, Penegakan Hukum Progresif, Penerbit Buku Kompas, Jakarta

Soehino, Ilmu Negara, liberty, Yogyakarta

Sri Soemantri Martosoewignjo, 1976, Sistem-Sistem Pemerintahan Negara-Negara ASEAN, Bandung, Tarsito

Suteki, 2013 Desain Hukum Dalam Ruang Sosial, Tahafa Media, Yogyakarta

Talizudhu Ndraha, 1981, Dimensi-dimensi Pemerintahan Desa, Bina Aksara, Jakarta,

Zudan Arif Fakrulloh, 2004, Kebijakan Desentralisasi di Persimpangan, Cipruy, Jakarta 